\title{
Bouguer Anomaly Map of the \\ Eastern Mediterranean, the Dead Sea Rift and Western Jordan
}

by

Robert L. Kovach

31 December 1986

Department of Geophysics, Stanford University and U.S. Geological Survey, Menlo Park, California.

\author{
U.S. Geological Survey
}

Open File Report 87-9

This report is preliminary and has not been

edited or reviewed for conformity with

Geological Survey Standards and nomenclature 


\section{Table of Contents}

1. Introduction

2. Sources of Data

3. Bouguer Anomaly Map

4. Discussion of the Map

5. Acknowledgments

6. References 


\section{List of Figures}

Figure 1-1: Index Map Showing Area of Interest 2

Figure 3-1: Bouguer Anomaly Map

4

Figure 4-1: NW-SE Bouguer Gravity Profile Crossing the eastern

Mediterranean- Continental Transition Zone and the Dead Sea Rift 


\section{Introduction}

As part of a study to understand the seismicity, tectonics and crustal structure of the Dead Sea Rift and western Jordan (Kovach et al, 1986ab) it is important to make use of many types of geophysical data. Gravity data are of particular use in constraining crustal models and for extrapolation into regions lacking seismic control.

Certainly the gravity field of parts of the Middle East and the Dead Sea Rift has been a source of interest since the early measurements of Von Triulzi (1898), Curry (1913), Vening Meinesz (1934) and Lejay (1938). In the purview of plate tectonics, the region is of interest because of the postulated change in mode from expansion or spreading in the Red Sea to a mixture of spreading and shear in the Gulf of Suez and the Dead Sea Rift - hence the term leaky transform fault.

Much of the gravity data for the region of interest, bordered by Cyprus, Lebanon and Syria in the north, western Jordan on the east and encompassing the Sinai Peninsula and the Gulf of Suez shown in (Figure 1-1) is only available with segmented relative surveys not readily available and which have not been presented as a unified Bouguer gravity anomaly map.

\section{Sources of Data}

Data for Lebanon and a portion of Syria were taken from the published map of Tiberghien (1974). Gravity data for Israel were compiled from various maps presented by Ginzburg (1970), Ginzburg and Makris (1979), Folkman (1976, 1980, 1981), Folkman and Bein (1978) and Makris (1978) and checked against individual station data reported by LeJay (1938), Knopoff and Belshe (1966) and the Royal Jordanian Army available in the data banks of the Defense Mapping Agency, St. Louis.

Gravity data for the Gulf of Aqaba are available from Allan and Morelli (1970) and BenAvraham (1985). For the Sinai Peninsula and the Gulf of Suez the gravity data are taken from Riad (1977) and Folkman and Assael (1980). Gravity data for western Jordan are taken from Abu-Ajamieh (1973) and checked against recent gravity observations on the rugged eastern escarpment of the Dead Sea Rift as part of a geothermal resource assessment program (Andreasen and Kovach, unpublished). For the eastern Mediterranean published maps of Woodside (1976) and Woodside and Bowin (1970) were utilized. 
Figure 1-1: Index Map Showing Area of Interest

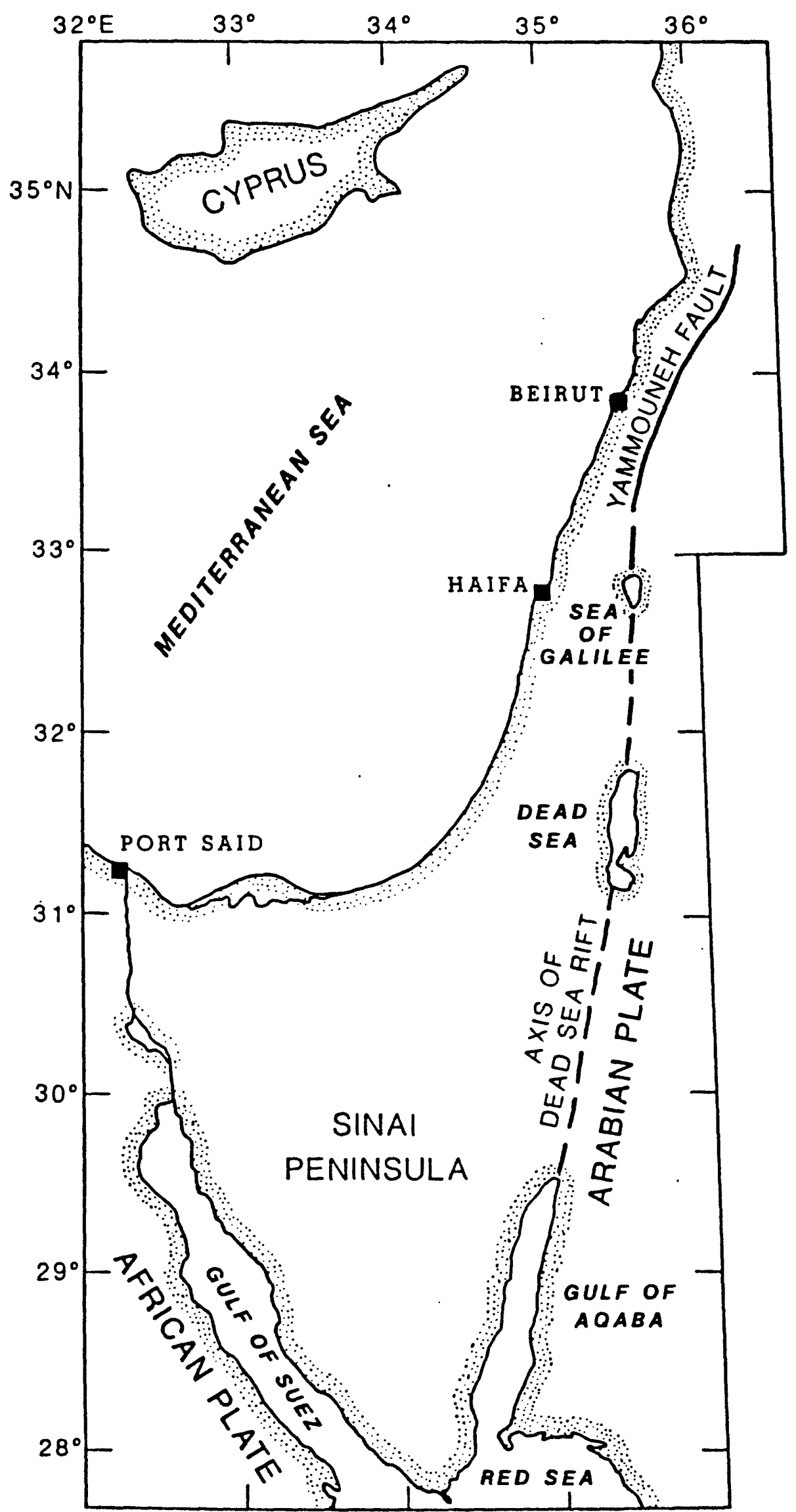




\section{Bouguer Anomaly Map}

In constructing the Bouguer anomaly map shown in (Figure 3-1) a contour interval of 10 mgals was used for the land values and a contour interval of 20 mgals for the anomaly values in the eastern Mediterranean. All of the published relative anomaly maps were adjusted to the base level of Tiberghien's published map and the contour values subsequently checked against individual station data. The map compiled in (Figure 3-1) is thus adjusted to a gravity base station in Beirut which has been tied to the world-wide base in Potsdam (981274 mgal). A preliminary version was presented at the 1980 meeting of the American Geophysical Union (Kovach and Ben-Avraham, 1980) and various gravity profiles were discussed by Kovach and Ben-Avraham (1985).

For the gravity field of the eastern Mediterranean a Bouguer anomaly was utilized rather than the free-air anomaly. To obtain an anomaly map which reflects sub-bottom changes it is necessary to correct for the variations in water depth. The correction applied is the increase in gravity at a particular observation point which would occur if the sea water is replaced by rock of a specified density, in this case $2.67 \mathrm{~g} / \mathrm{cm}^{3}$, as utilized for the land observations.

\section{Discussion of the Map}

The Bouguer anomaly values range from +200 mgals over Cyprus to less than -110 mgals at the southern end of the Dead Sea. Anomaly values are positive in the eastern Mediterranean, as expected for an oceanic region. The Bouguer anomaly values increase northward from a value of about 0 mgals at the shoreline at the Suez Canal to values in excess of +100 mgals reflecting sediment deposition in the Nile Cone.

At the southern tip of the Sinai Peninsula the gravity field switches from positive to negative values in the Gulfs of Suez and Aqaba. Both the Gulfs of Suez and Aqaba are characterized by gravity minima with the values in the Gulf of Suez approximately one-half those found in the Gulf of Aqaba.

Along the Dead Sea Rift itself the Bouguer anomaly field is characterized by very steep gradients towards the Rift Zone and a series of strong negative gravity closures from north to south. These closures are roughly centered in the Beka'a (Lebanon), the Hula Basin, south of the Sea of Galilee and at the southern end of the Dead Sea. Two sharp closures of a magnitude of about - 100 mgals are found in the Gulf of Aqaba in the vicinity of the Elat and Dakar-Aragonese bathymetric deeps (Ben-Avraham, 1985). 
Figure 3-1: Bouguer Anomaly Map

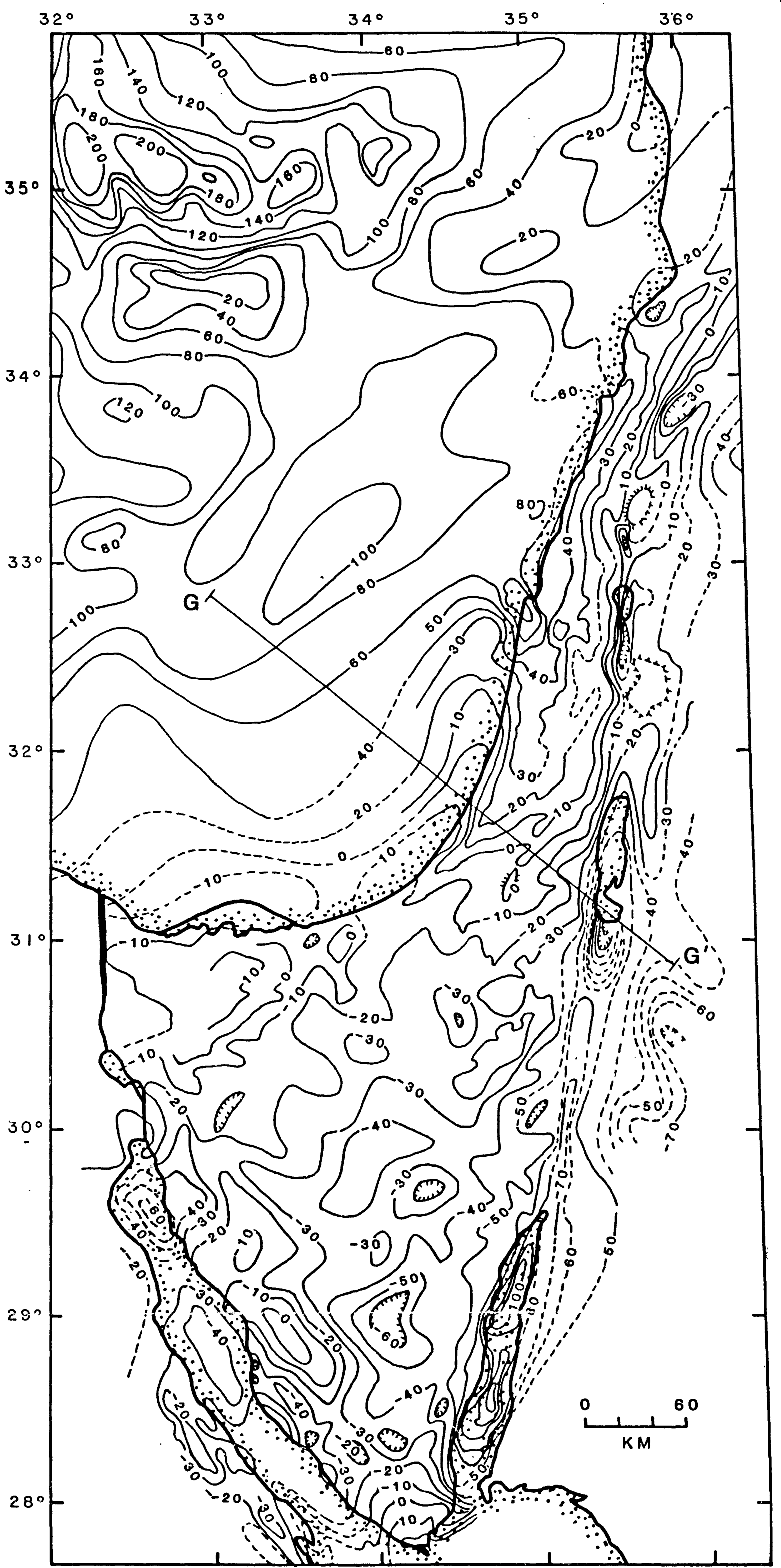


(Figure 4-1) is a $350 \mathrm{~km}$ long NW-SE gravity profile crossing the eastern Mediterraneancontinental transition zone and the Dead Sea Rift. Also shown is a computed 2-D gravity model. In constructing the gravity model seismic refraction data at sea (Ben-Avraham et al, 1979) and on land (Ginzburg et al, 1979) were used to fix the depth to the various horizons and conventional velocity-density systematics were used to assign representative densities to the various layers.

Noteworthy on the profile are the rapid transition between the eastern Mediterranean Sea and the continental borderland as reflected in the pinchout of the oceanic $4.5 \mathrm{~km} / \mathrm{sec}$ layer and the change in Moho velocity landward from $8.0 \mathrm{~km} / \mathrm{sec}$ to $7.8 \mathrm{~km} / \mathrm{sec}$. The southern Dead Sea Rift zone is characterized by a sharp negative anomaly in excess of -90 mgals and the modeling illustrates that the gravity anomaly is produced by $8-9 \mathrm{~km}$ of low density $\left(2.0 \mathrm{gm} / \mathrm{cm}^{3}\right)$ material so that the bordering faults must extend to at least that depth. Additional gravity observations are needed in western Jordan so that the profile can be extended further eastward. Without these data it cannot be determined whether crustal thinning occurs across the rift zone.

\section{Acknowledgments}

This research was indirectly supported by the Natural Resources Authority of the Hashemite Kingdom of Jordan and the United States Agency for International Development. 
Figure 4-1: NW-SE Bouguer Gravity Profile Crossing the eastern MediterraneanContinental Transition Zone and the Dead Sea Rift

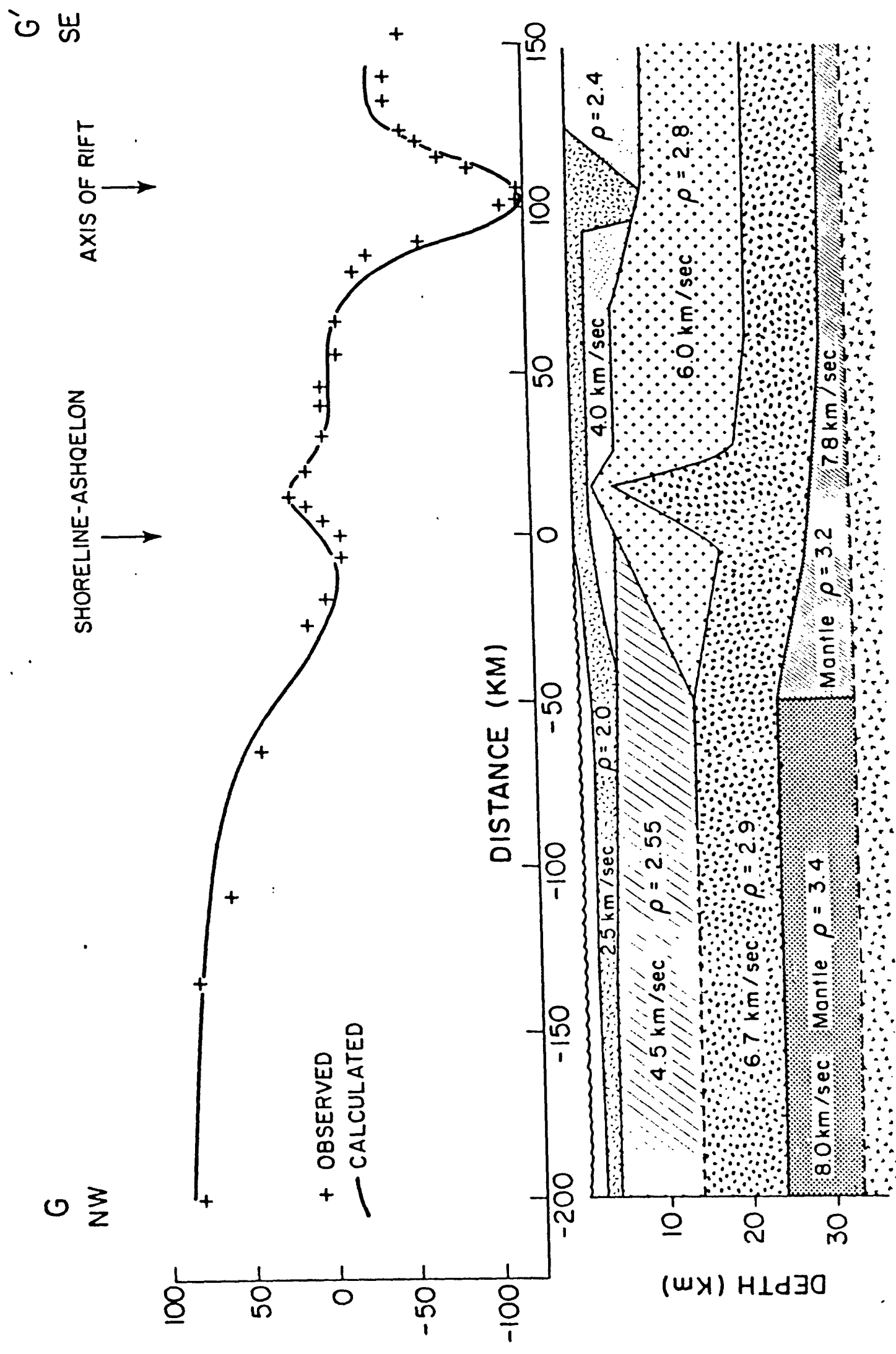




\section{References}

1. Abu-Ajamieh, M., Regional Gravity Map of Jordan, Natural Resources Authority, Amman, Jordan, Scale 1:250,000, (1973).

2. Allan, T.D. and Morelli, C., The Red Sea, in: The Sea, 4, part 2, (A.E. Maxwell, ed.) Wiley-Interscience, NY, 493-542, (1970).

3. Ben-Avraham, Z., Structural Framework of the Gulf of Elat (Aqaba), Northern Red Sea, Journal of Geophysical Res., 90, 703-726, (1985).

4. Ben-Avraham, Z., Behle, A., Makris, J., Ginzburg, A., Geise, P., Steinmetz, L., and Whitmarsh, R.B., Crustal Structure of the Eastern Mediterranean: A Seismic Refraction Profile from Israel to Cyprus, EOS, Trans. Am. Geophys,. Union, 60, 886-887, (1979.

5. Curry, P.A., The Value of Gravity at Eight Stations in Egypt and the Sudan, Survey Dep. Egypt, Paper 18, (1913).

6. Folkman, Y., Magnetic and Gravity Investigations of the Crustal Structure in Israel, Ph.D. Thesis, Tel-Aviv University, (1976).

7. Folkman, Y., Magnetic and Gravity Investigations of the Dead Sea Rift and Adjacent Areas in Northern Israel, J. Geophys., 48, 34-39, (1980).

8. Folkman, Y., Structural Features in the Dead Sea-Jordan Rift Zone, Interpreted from a Combined Magnetic-Gravity Study, Tectonophysics, 80, 135-146, (1981).

9. Folkman, Y. and Bein, A., Geophysical Evidence for a pre-Jurassic Fossil Continental Margin Oriented East-West under Central Israel, Earth Plan. Sci. Lett., 39, 335-340, (1978).

10. Folkman, Y. and Assael, R., Sinai Gravity Map, Institute for Petroleum Research and Geophysics, Israel, Scale 1:500,000, (1980).

11. Ginzburg, A., The Gravity Map of Israel, in Atlas of Israel (2nd ed.), Survey of Israel, Jerusalem and Elsevier, Amsterdam (1970).

12. Ginzburg, A. and Makris, J., Gravity and Density Distribution in the Dead Sea Rift and Adjoining Areas, Tectonophysics, 54, T17-T25, (1979).

13. Ginzburg, A., Makris, J., Fuchs, K., Prodehl, C., Kaminski, W., and Amitai, U., A Seismic Study of the Crust and Upper Mantle of the Jordan-Dead Sea Rift and their Transition Toward the Mediterranean Sea, J. Geophysical Research, 84, 1569-1582, (1979).

14. Kovach, R.L., Andreasen, G., Gettings, M. and Healy, J., The Jordan Seismological Observatory, U.S. Geological Survey Open File Report 86-384, 18pp., (1986a).

15. Kovach, R.L., and Ben-Avraham, Z., Gravity Anomalies and Inferred Crustal Structure of the Eastern Mediterranean Region, EOS, Trans. Amer. Geophysical Union, 61, p. 1100, (1980).

16. Kovach, R.L., Andreasen, G., Gettings, M. and Healy, J., Seismicity of Western Jordan, U.S. Geological Survey Open File Report 86-561, 28pp., (1986b). 
17. Kovach, R.L. and Ben-Avraham, Z., Gravity Anomalies Across the Dead Sea Rift and Comparison with other Rift Zones, Tectonophysics, 111, 155-162, (1985).

18. Knopoff, L. and Belshe, J.C., Gravity Observations of the Dead Sea Rift, Geol. Surv. Canada, Paper 66-19, 5-21, (1966).

19. Lejay, R.P.R., Exploration Gravimetrique des Etats du Levant Sous Mandat Francais, Comité Nat. Fr. Géol. Géophys., 54p, (1938).

20. Makris, J., Some Geophysical Considerations on the Geodynamic Situtation in Greece, Tectonophysics, 46, 251-268, (1978).

21. Riad, S., Shear Zones in North Egypt Interpreted from Gravity Data, Geophysics, 42, 1207-1214, (1977).

22. Tiberghien, M.W., Anomalies de Bouguer et Structure Profonde de Liban, C.R. Acad. Sci. Paris T. Ser. D., 278, 2401-2404, (1974).

23. Vening Meinesz, F.A., Gravity Expeditions at Sea, II, 1923-32, Delft.

24. Von Triulzi, A.E., Expedition S.M. Schiff Pola in das Rothe Meer, nördliche Hälfte. Wissenschaftliche Ergebnisse, XII, Relative Schwerebistimmung, Denkschr. K. Akad. Wiss. Math.-Nat. Classe, 65, 131-206, (1898).

25. Woodside, J.M., Regional Vertical Tectonics in the Eastern Mediterranean, Geophys. J.R. Astr. Soc., 47, 493-514, (1976).

26. Woodside, J. and Bowin, C., Gravity Anomalies and Inferred Crustal Structure in the Eastern Mediterranean Sea, Geological Society of America Bulletin, 81, 1107-1122, (1970). 